\title{
INVESTIGATION OF AN OUTBREAK OF SALMONELLA TYPHI IN BATTALGAZI DISTRICT, MALATYA-TURKEY
}

\author{
Latife Iseri $^{1 *}$; Mehmet Refik Bayraktar²; Elif Aktaş³ $^{3}$ Riza Durmaz $^{2}$ \\ ${ }^{1}$ Department of Medical Microbiology, Faculty of Medicine, Kırıkkale University, Kırikkale, Turkey; ${ }^{2}$ Department of Medical \\ Microbiology, Faculty of Medicine, Inonu University, Malatya, Turkey; ${ }^{3}$ Department of Medical Microbiology, Faculty of \\ Medicine, Karaelmas University, Zonguldak, Turkey
}

Submitted: February 06, 2008; Returned to authors for corrections: April 09, 2008; Approved: February 25, 2009.

\begin{abstract}
Salmonella Typhi infections are important public health problems for the developing countries. In this study we investigated the molecular epidemiology of a suspected well-water borne S. Typhi outbreak occurred in a district of Malatya-Turkey. This outbreak affected 10 patients in two days. Arbitrary primed polymerase chain reaction (AP-PCR) based typing showed two clones, one had seven, and the other had three strains, supporting outbreak speculation. By adding chlorine to wells by local municipal authority, the outbreak ended within a very short time (about ten days).
\end{abstract}

Key words: Typhoid fever; Salmonella Typhi, waterborne outbreak

\section{INTRODUCTION}

Infections caused by Salmonella enterica serotype Typhi (S. Typhi) are important public health problems for the developing countries. This bacterium is endemic in many parts of world causing typhoid fever $(2,4,7,11,18)$. Typhoid fever is a severe and life-threatening systemic illness transmitted via the fecal-oral route and is a major cause of morbidity and mortality worldwide. It causes over 16 million new cases and over 600,000 deaths each year (1). Outbreaks of typhoid fever caused by multidrug-resistant strains have been encountered recently $(17,19)$ and they pose therapeutic challenges for physicians. The typhoid infections is most frequently in less industrialized countries where sanitary conditions remain poor and water supply is untreated $(10,11,17)$. In industrially developed countries, the total incidence is low and usually associated with travel to endemic regions $(8,9,12,16)$.

Typhoid fever is a serious problem in particularly southeast Turkey, where 10000 patients are diagnosed annually with this disease (5).

In this report, we investigate an outbreak caused by $S$. Typhi in Battalgazi district/ Malatya.

\section{MATERIALS AND METHODS}

\section{Isolation, identification and antimicrobial susceptibility}

The growth of $S$. Typhi in blood (7 isolates) and stool samples (3 isolates) of 10 individuals in two days at the Microbiology laboratory has attracted our attention. Epidemiology of patients was evaluated. All patients were from Battalgazi district and they were using the water of the same well as a source of drinking water. They did not have another common food or drinking source. Blood specimens were inoculated into blood culture system (BACTEC 9120, Becton Dickinson). They were subcultured onto eosin methylene blue (EMB) and Salmonella and Shigella (SS) media. Stool specimens were cultured on EMB, $\mathrm{SS}$ and Selenite F media.

Water samples $(3000 \mathrm{ml})$ from the suspected source of the water were taken aseptically. They were first centrifuged at 3000 $\mathrm{rpm}$ for 5 minutes. The sediment was aseptically dropped onto the surface of blood, EMB and SS agar media.

All strains were defined by conventional biochemical tests. They were confirmed with the API 20E system (bioMerieux, Marcy-1'Etiole, France) and were serotyped by slide agglutination with specific salmonella polyvalent and monovalent antisera

*Corresponding Author. Mailing address: Kırıkkale Üniversitesi, Tıp Fakültesi, Mikrobiyoloji Anabilim Dalı, Kırıkkale-Turkey. Tel.: 90 505 2663999. E-mail: liseri2000@yahoo.com 
(Denka Seiken Co. Ltd., Japan). A month after the outbreak, three more isolates were also encountered in our clinical microbiology laboratory.

Antimicrobial susceptibility testing was performed by using Kirby-Bauer Disk Diffusion Method according to NCCLS criteria (13). The antibiotic Discs tested (Oxoid, Oxoid limited, Wade Road, Basingstroke, Hampshire, RG24 8PW, United kingdom) were ampicillin $(10 \mu \mathrm{g})$, piparacillin $(100 \mu \mathrm{g})$, carbenicillin (100 $\mu \mathrm{g})$, sulbactam- ampicillin $(20 \mu \mathrm{g})$, cephalothin $(30 \mu \mathrm{g})$, ceftriaxone $(30 \mu \mathrm{g})$, ceftazidime $(30 \mu \mathrm{g})$, imipenem $(10 \mu \mathrm{g})$, meropenem (10 $\mu \mathrm{g})$, amikacin $(30 \mu \mathrm{g})$, ofloxacin $(5 \mu \mathrm{g})$, trimethoprimsulfamethoxazole $(1.25 / 23.75 \mu \mathrm{g})$, chloramphenicol $(30 \mu \mathrm{g})$.

\section{Molecular typing}

AP-PCR typing was performed for 10 strains isolated from the patients and three stains which were not related to outbreak. Arbitrarily primed polymerase chain reaction (AP-PCR) was used to evaluate the clonal relationship of the isolates. The DNA was extracted using proteinase $\mathrm{K}$ and precipitated by phenolchloroform following the protocol of Welsh and Mcclelland (20). AP-PCR optimized previously was performed with M13 primer $(3,14)$. We interpreted the results as described before (14).

\section{RESULTS}

All of the Salmonella species in the samples of patients were identified as $S$. Typhi. As water collection was carried out 5 days after the first isolation of $S$. Typhi from the patients and at that time the well was disinfected by adding chlorine to wells by local municipal authority, no salmonella species were obtained from cultures of the well-water samples. The characteristics of the samples and isolates are shown in Table 1. Isolates 5 and 6 were resistant to cephalothin whereas isolates 8 and 9 were intermediately susceptible to this antibiotic. The other isolates were susceptible to all antibiotics tested. None of the isolates was positive for Extended Spectrum Beta Lactamase (ESBL). The outbreak ended in a very short time (about ten days).

\section{Molecular typing of the isolates}

According to the results of the AP-PCR typing, there were two clusters with seven and three members, each. These ten isolates were obtained from cultures in a two-day period. Two isolates obtained from patients in the same village 15 and 30 days after the outbreak. One isolate was epidemiologically unrelated to the outbreak (i.e. from a patient from another city) showed unique profiles. The AP-PCR typing of the isolates are shown in Table 1. The gel image of the AP-PCR is shown in Fig. 1 . The ten isolates obtained during the outbreak period were clustered in two AP-PCR groups designated by profiles $\mathrm{E}$ and D. Four blood isolates and three stool isolates showed profile E while three isolates from blood demonstrated profile $\mathrm{D}$.
Table 1. Some characteristics of the $S$. Typhi strains.

\begin{tabular}{clccc}
\hline $\begin{array}{c}\text { Stain } \\
\text { No }\end{array}$ & \multicolumn{1}{c}{$\begin{array}{c}\text { Clinical } \\
\text { samples }\end{array}$} & $\begin{array}{c}\text { Origin of } \\
\text { the patients }\end{array}$ & $\begin{array}{c}\text { Isolation } \\
\text { date }\end{array}$ & $\begin{array}{c}\text { AP-PCR } \\
\text { profile }\end{array}$ \\
\hline 1 & Blood & Battalgazi & 30.06 .2003 & A \\
2 & Blood & Adiyaman & 11.07 .2003 & B \\
3 & Stool & Battalgazi & 18.06 .2003 & C \\
4 & Blood (sibling 4, 5, 6) & Battalgazi & 29.05 .2003 & D \\
5 & Stool (sibling 4, 5,6) & Battalgazi & 29.05 .2003 & E \\
6 & Stool (sibling 4, 5, 6) & Battalgazi & 29.05 .2003 & E \\
7 & Blood & Battalgazi & 29.05 .2003 & E \\
8 & Blood & Battalgazi & 29.05 .2003 & E \\
9 & Blood & Battalgazi & 29.05 .2003 & E \\
10 & Blood & Battalgazi & 28.05 .2003 & D \\
11 & Blood & Battalgazi & 28.05 .2003 & E \\
12 & Blood & Battalgazi & 28.05 .2003 & D \\
13 & Stool & Battalgazi & 28.05 .2003 & E \\
\hline
\end{tabular}

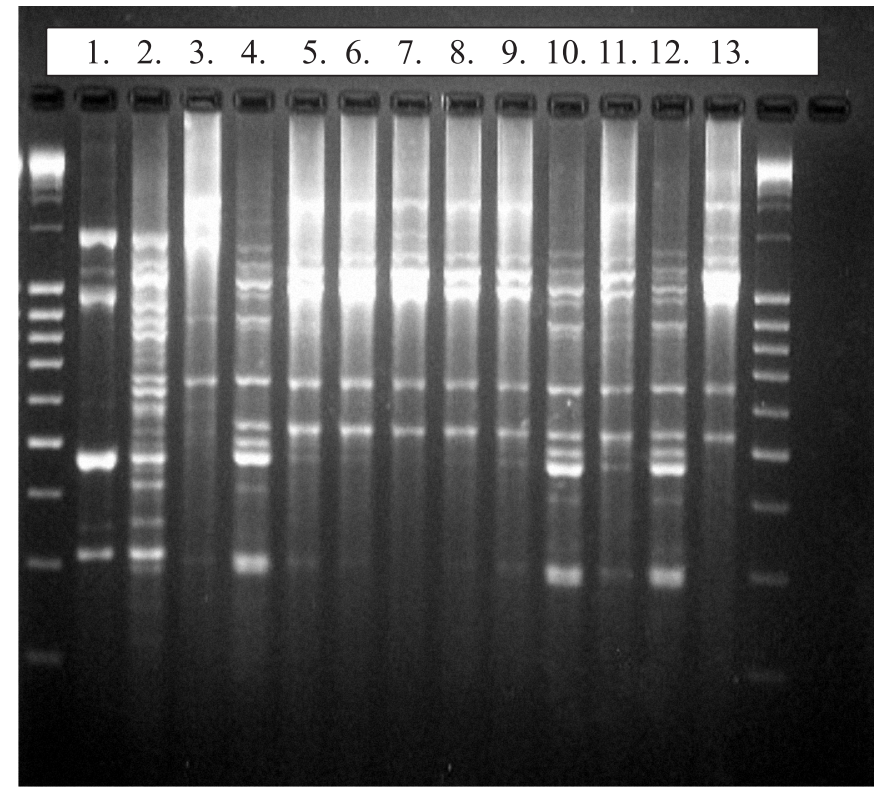

Figure 1. AP-PCR typing results of 13 strains. Lines 1,2 and 3 were the strains which did not relate to outbreak. Lines 4,10 , and 12 belonged to the same clone (clone $\mathrm{D}$ in table), Lines 5-9, 11 , and 13 belonged to the second same clone (clone $\mathrm{E}$ in table). The lines at the beginning and end of the gel were molecular weight marker.

\section{DISCUSSION}

The most common source of $S$. Typhi infections is drinking water tainted by urine and feces of infected individuals. Waterborne $S$. Typhi outbreaks from various countries were notified 
from time to time $(6,10,21)$. Upon its isolation from blood (7 isolates) and stool samples ( 3 isolates) of 10 individuals within two days at the Clinical Microbiology laboratory, an outbreak investigation study was performed including molecular epidemiological studies by AP-PCR method. When the epidemiological relationship of the patients was analyzed, it was noticed that all the patients lived in the same area. With further investigation, it was noticed that they had been using the same well as water source at their district. The well water was considered as the suspected source of the outbreak. The water samples obtained from well did not yield $S$. Typhi. This may be due to over chlorination of water. Nevertheless, we think that the water is the possible source of infection. The other less likely explanation for failure of well isolation may be bacteria present at very low concentrations in environmental water and more reproducible method was required to detect them. It is also possible that dilution of the bacteria by the well water precluded their isolation

According to AP-PCR, the ten isolates were obtained during the outbreak period were clustered in two groups designated by profiles E and D. Four blood isolates and three stool isolates showed profile $\mathrm{E}$ while three isolates from blood demonstrated profile D. Interestingly, one blood isolate of a patient from a particular family demonstrated profile D whereas two stool samples from two siblings in the same family showed profile $\mathrm{E}$. We consider that the same source could be infected with more than one clone of $S$. Typhi, or it is most probable that AP-PCR misclassified these strains. We educated the people in the village about the route of infection and sanitation. We gave information to the town council about the situation and warned about the probable source of infection.

Three new typhoid cases, hospitalized in the same ward where previous outbreak patients stayed, were detected in our clinical microbiology laboratory within month post the last outbreak. Two of them, were from a village of same district. The third one was from other city (Adiyaman). These three isolates were also investigated by AP-PCR. However, they showed unique profiles each and had no relationship with the outbreak isolates. We conclude that the outbreak was successfully controlled as there was no other isolates of $S$. Typhi from the same district in the following four months period.

In recent years, $S$. Typhi has gradually acquired resistance to many of the antibiotics used and this increases the importance of $S$. Typhi outbreaks all over the world. Multiple antibioticresistant strains for primary drugs (ampicillin, chloramphenicol, co-trimoxazole and tetracycline) have been reported in many countries $(4,10,15,17,19)$. In this study, isolated strains were mostly sensitive with no ESBL ones. Only two strains showed resistance to cephalothin.

In conclusion, water-born $S$. Typhi outbreaks can be significant public health problem. Sanitation and cleanliness of the drinking water is very important. Outbreak investigation by molecular epidemiological studies has considerable importance for tracing course of the outbreak, controlling infection and preventing its spread.

\section{RESUMO}

\section{Investigação de um surto de Salmonella Typhi no distrito de Battalgazi, Malatya, Turquia}

As infecções por Salmonella Typhi são problemas importantes de saúde pública em países em desenvolvimento. Neste estudo, investigamos a epidemiologia molecular de surto de Salmonella Typhi, supostamente causado por água de poço, ocorrido no distrito de Battalgazi, Malatya, Turquia. Este surto afetou 10 pessoas em dois dias. A tipagem por AP-PCR (arbitrary primed polimerase chain reaction) indicou dois clones, um com sete isolados e outro com três isolados. Com a adição de cloro aos poços pelas autoridades locais, o surto terminou rapidamente (em dez dias).

Palavras-chave: febre tifóide, Salmonella Typhi, surto causado por água

\section{REFERENCES}

1. Aye, T.T.; Siriarayapon, P. (2004). Typhoid Fever outbreak in Madaya Township, Mandalay Division, Myanmar, September 2000. J. Med. Assoc. Thai., 87, 395-399.

2. Costalunga, S.; Tondo, E.C. (2002). Salmonellosis in Rio Grande Do Sul, Brazil, 1997 TO 1999. Braz. J. Microbiol. 33, 342-346

3. Grundmann, H.J.; Towner, K.J.; Dijkshoom, L.; Gerner-Smıdt, P.; Maher, M.; Seifert, H.; Vaneechoutte, M. (1997). Multicenter study using Standardized protocols and reagents for evaluation of reproducibility of PCR based fingerprinting of Acinobacter spp. $J$. Clin. Microbiol. 35, 3071-3077.

4. Kariuki, S.; Revathi, G.; Muyodi, J.; Mwituria, J.; Munyalo, A.; Mirza, S.; Hart, C.A. (2004). Characterization of multidrug-resistant typhoid outbreaks in Kenya. J. Clin. Microbiol. 42, 1477-1482.

5. Hosoglu, S.; Celen, M.K.; Geyik, M.F.; Akalin, S.; Ayaz, C.; Acemoglu, H.; Loeb, M. (2006). Risk factors for typhoid fever among adult patients in Diyarbakir, Turkey. Epidemiol. Infec. 134, 612-616.

6. Katz, D.J.; Cruz, M.A.; Trepka, M.J.; Suarez, J.A.; Fiorella, P.D.; Hammond, R.M. (2002). An outbreak of typhoid fever in Florida associated with an imported frozen fruit. J. Infect. Dis. 186, 234239.

7. Le, T.A.; Lejay-Collin, M.; Grimont, P.A.; Hoang, T.1.; Nguyen, T.V.; Grimont, F.; Scavizzi, M.R. (2004). Epidemic Clone of Salmonella enterica Serovar Typhi Harboring a Single MultidrugResistant Plasmid in Vietnam between 1995 and 2002. J. Clin. Microbiol. 42, 3094-99.

8. Lewis, H.C.; Lawrence, J. (2006). Recent increase in S. Paratyphi A phage type 1 and $S$. Typhi Vi-phage type E1 in England and Wales, associated with travel to the Indian subcontinent. Euro Surveill. 11 (10), 2921.

9. Meltzer, E.; Sadik, C.; Schwartz, E. (2005). Enteric Fever in Israeli Travelers: A Nationwide Study. J. Travel Med. 12, 275-281.

10. Mermin, J.H.; Villar, R.; Carpenter, J.; Roberts, L.; Samaridden, A.; Gasanova, L.; Lomakına, S.; Bopp, C.; Hutwagner, L.; Mead, P.; Ross, B.; Mintz, E.D. (1999). A epidemic of multidrug-resistant 
typhoid fever in Tajikistan associated with consumption of municipal water. J. Infect. Dis. 179, 1416-1422.

11. Mirza, S.; Kariuki, S.; Mamun, K.Z.; Beeching, N.J.; Hart, C.A. (2000). Analysis of Plasmid and Chromosomal DNA of MultidrugResistant Salmonella enterica Serovar Typhi from Asia. J. Clin. Microbiol. 38, 1449-1452.

12. Muehlen, M.; Frank, C; Rabsch, W.; Fruth, A.; Suckau, M.; Moeller, I.; Gronemann, B.; Prager, R.; Ruf, B.; Grunewald, T.; Ammon, A.; Stark, K.; Alpers, K. (2007). Outbreak of domestically acquired typhoid fever in Leipzig, Germany, June 2004. Euro Surveill. 12 (2), 684

13. NCCLS. (2005). Performance standards for antimicrobial disk susceptibility tests M2-A6. Wayne, Pennsylvania.

14. Ozerol, I.H.; Bayraktar, M.R.; Iseri, L.; Otlu, B.; Durmaz, R. (2005). The prevalence and molecular typing of enterotoxigenic Eschericha coli, strains isolated from diaeeheic stools in Malatya, Turkey. New Microbiol. 28, 237-243.

15. Pereira, C.S.; Medeiros, L.M.; Costa, R.G.; Festivo, M.L.; Dos Reis, E.M.F.; Seki, L.M.; Dos Prazeres Rodrigues, D. (2007). Phage typing and multidrug resistance profile in $S$. typhimurium isolated from different sources in Brazil from 1999 to 2004. Braz. J. Microbiol. $38,385-390$.
16. Pradier, C.; Keita-Perse, O.; Bernard, E.; Gisbert, C.; Vezolles, M.J.; Armengaud, A.; Carles, D.; Grimont, F.; Desenclos, J.C.; Dellamonica, P. (2000). Outbreak of Typhoid Fever on the French Riviera Eur. J. Clin. Microbiol. Infect. Dis. 19: 464-467

17. Rathish, K.C.; Chandrashekar, M.R.; Nagesha, C.N. (1995). An outbreak of multidrug resistant typhoid fever in Bangalore. Indian J. Pediatr. 62, 445-448.

18. Shanahan, P.M.; Jesudason, M.V.; Thomson, C.J.; Amyes, S.G. (1998) Molecular analysis of and identification of antibiotic resistance genes in clinical isolates of Salmonella typhi from India. J. Clin. Microbiol. $36,1595-1600$

19. Swaddiwudhipong, W.; Kanlayanaphotporn, J. (2001). A commonsource water-borne outbreak of multidrug-resistant typhoid fever in a rural Thai community. J. Med. Assoc. Tha. 84, 1513-1517.

20. Welsh, J.; Mcclelland, M. (1993). In: Persing, D.H., Smith, T.F., Tenover, F., and White, T.J., eds. Diagnostic molecular microbiology. Principles and applications. Washington, DC: Am. Soc. Microbiol. pp. 595-602.

21. Wohlsen, T.; Bates, J.; Vesey, G.; Robinson, W.; Katoull, M. (2006) Evaluation of the methods for enumerating coliform bacteria from water samples using precise reference standards. Lett. Appl. Microbiol. 42, 350-356. 